\title{
A Philosophical Approach to Entrepreneurial Education: A model based on Kantian and Aristotelian thought
}

\author{
Massimiliano Matteo Pellegrini \\ Assistant Professor in Business and Management \\ Università di Roma Tor Vergata \\ Via Columbia, 2, 00133 Roma RM, Italia \\ massimiliano.pellegrini@uniroma2.it \\ Cristiano Ciappei \\ Full Professor in Strategy \\ University of Florence - Department of Sciences for Business \& Economics \\ Via delle Pandette, 32 - 50127 Firenze, Italy \\ cristiano.ciappei@unifi.it \\ Giacomo Marzi \\ Lecturer in Strategy \\ Lincoln International Business School - University of Lincoln \\ Brayford Wharf E, LN5 7AT, Lincoln (UK) \\ gmarzi@lincoln.ac.uk \\ Marina Dabić (Corresponding Author) \\ Full Professor in International Economics \\ University of Zagreb, Faculty of Economics and Business \\ 10000 Zagreb, Croatia \\ $\&$ \\ Nottingham Trent University, Nottingham Business School \\ Burton street \\ Nottingham NG14BU \\ mdabic@efzg.hr \\ Carolyn Egri \\ Professor, Management and Organization Studies \\ Beedie School of Business \\ 8888 University Drive, Burnaby, B.C, Canada V5A 1S6 \\ egri@sfu.ca
}

\section{Author's Bio:}

Massimiliano M. Pellegrini is currently working at University of Rome "Tor Vergata", as a qualified associate professor (assistant professor with national qualification). From the same university he also received his Ph.D. in 2011. Previously, he was a Senior lecturer at Roehampton University and he covered several roles as permanent staff at University of West London and Princess Sumaya University, and visiting staff at the Wharton School, University of Linz, University of Enlarger-Nuremberg. He was the Chair for 
the Strategic Interest Group of Entrepreneurship (E-ship SIG) at the European Academy of Management (EURAM) until 2018. His research interests and publications are focused on entrepreneurial, ethical, and organizational behaviours; he published more than 40 contributions especially in highly-ranked journals e.g., J. of Business Ethics, J. of Managerial Psychology, Int. J. of Entrepreneurial Behaviours \& Research, Int. J. of Entrepreneurship \& Small Business, and Business Process Management J.

Cristiano Ciappei is a Full professor at the Faculty of Economics at the University of Florence. He has taught at numerous Italian and foreign universities including the Campus Biomedico University of Rome and the Fashion Institute of Technology at the State University of New York. Author of numerous scientific publications especially in the field of entrepreneurship and business ethics.

Giacomo Marzi received the Ph.D. degree in management, from the University of Pisa, Pisa, Italy, in, 2018. $\mathrm{He}$ is Lecturer in strategy and enterprise with the, Lincoln International Business School, University of, Lincoln, Lincoln, U.K. He carried out research activities, as a Visiting Scholar at the University of Zagreb, Zagreb, Croatia. He has authored and co-authored a, number of papers that appeared in conferences, edited, books, and journals, including the Journal of Business, Research, the International Journal of Conflict Management, the International Journal of Innovation and Technology Management, Scientometrics, and the Business Process Management Journal. His research interests include innovation management and entrepreneurship.

Professor Marina Dabić is the author of more than 200 articles and case studies, and has edited five books. A monography written by Marina Dabić, Jadranka Švarc, and Miguel Gonzales-Loureiro, entitled Entrepreneurial Universities in Innovation-Seeking Countries: Challenges and Opportunities was published by Palgrave Macmillan in 2016. Her papers appear in wide variety of international journals, including the JIBS, JWB, TFSC, IEEE-TEM, JBR, IMR, MIR, Organizational Dynamics among many others. Prof Dabic is associate editor of the IEEE- Transaction of Management, Technology in Society, and Journal of Knowledge Economy. In her career, Dr Dabić has achieved success, acclaim in a range of different projects HORIZON 2020, ERASMUS +, LLL Leonardo da Vinci, and is a primary supervisor for TEMPUS FoSentHE project granted by the European Commission. She is continuously reviewer for EC Horizon 2020 projects.

Dr. Carolyn Egri is the William J.A. Rowe EMBA Alumni Professor, and professor of management and organization studies. Carolyn is a pioneer in research related to corporate environmental and social responsibility - she has been publishing on this topic for more than 20 years, long before it became trendy. "It's meaningful work," she says. "Since it's a relatively new field, it's very exciting - there's the opportunity to develop new standards and ideas.", , Carolyn makes leadership and environmental sustainability the focus of her teaching, both for the Beedie School of Business and for other organizations. She is a recipient of the David L. Bradford Outstanding Educator Award (Organizational Behavior Teaching Society for Management Educators) and TD Canada Trust Distinguished Teaching award., , A prolific researcher, she has been examining corporate environmental social responsibility practices as well as cross-cultural differences in managerial values and influence tactics around the world. Carolyn devotes much of her time to service in her academic community; she has been an Associate Editor for the Academy of Management Learning \& Education journal, and a chair of the Academy of Management's Organizations and the Natural Environment interest group. She has also been a director of the Organizational Behavior Teaching Society and serves on a variety of academic journal editorial boards. 


\title{
A Philosophical Approach to Entrepreneurial Education:
}

\section{A model based on Kantian and Aristotelian thought}

\begin{abstract}
In the field of entrepreneurship education, how to develop an effective program to teach entrepreneurship has been widely debated. However, an inductive approach based on analysis of educational program experiences and outcomes has led to mixed conclusions about the appropriate scope and structure of entrepreneurship education. In contrast, we take a deductive approach to develop a comprehensive entrepreneurship education model based on concepts from two schools of philosophical thought: the Kantian debate about freedom versus determinism, and the Aristotelian concepts of praxis and poïesis. These philosophical concepts are related to scope and structure dimensions that delineate the soft (art) and hard (science) of entrepreneurship education, their components and interrelationships. Pedagogies associated with each component as well as integrative pedagogies are identified to guide the development of entrepreneurship education programs and teaching. Theoretical propositions are presented for future research.
\end{abstract}

Key words: entrepreneurship education, philosophy of entrepreneurship, entrepreneurial acting, entrepreneurship pedagogies, art and science of entrepreneurship, Aristotle, Kant. 


\section{Introduction}

Entrepreneurship education has received significant attention from scholars, educators, practitioners, and policy-makers (Lee et al., 2005; Winkler, 2014). This attention is due to the fundamental role that entrepreneurial activity plays in modern societies through increasing formation of new ventures and bringing innovations to the market (Schumpeter, 1934), sustaining or increasing employment and job markets (e.g., Rideout and Gray, 2013), and ultimately contributing to national economic wealth (e.g., GEM, 2014). Thus, entrepreneurship education while transferring content knowledge and developing skills and competencies, should also stimulate intentions and mindsets that promote entrepreneurial behaviours and activities (Dana, 1992; Dana, 2001; Liñán, 2001; Gielnik et al., 2015; Liñán, 2004, 2008; Zhang et al., 2014). Despite this increased attention, the legitimacy of entrepreneurial education is far from well established (Abaho et al., 2015; Nabi et al., 2017; Tan and Ng, 2006). Business schools and training centres have implemented a variety of epistemological, theoretical, pedagogical and practical approaches under the conceptual umbrella of entrepreneurship (Fayolle, 2008, 2013; Fayolle and Gailly, 2015). In their classification of entrepreneurship education pedagogies and practices, Bechard and Gregoire (2007) delineated three different models: (i) Supply model based on a traditional approach to teaching and standardised courses; (ii) Demand model based on a personalised learning style with student-led seminars and experimentation; (iii) Competence model based on real projects in an actual (or simulated) industry environment. The debate about how to educate entrepreneurs identified by Gorman et al. (1997) is still vivid as shown by Nabi et al.'s (2017) recent systematic review. Further, this diversity in approaches has resulted in conflicting findings regarding the effectiveness of entrepreneurship education and constrained the development of a clear pedagogical approach (Fayolle and Gailly, 2008, 2015; Shinato et al., 2013; Nabi et al., 2017).

In this paper, we present a theoretical framework that responds to calls for revisiting the philosophical foundations of 'acting' that is one of the most central elements of entrepreneurship (Frese, 2009; McMullen and Shepherd, 2006) as well as vital to entrepreneurship education (Gielnik et al., 2015; Morris et al., 2013). Our model for entrepreneurship education integrates two cornerstones of Western philosophical theories, 
Aristotle (1968) and Kant (1790/1914), with modern concepts of entrepreneurship education. In particular, we focus on the scope of theoretical models of entrepreneurial potential and intentions (Krueger and Brazeal 1994; Krueger et al., 2000; Shapero and Sokol, 1982; Linan, 2011; Chen et al., 2015), and the structure of education in terms of content, knowledge and skills that can enact the entrepreneurial process (Chang and Rieple, 2013; Chell, 2013; Gielnik et al., 2015; Hood and Young, 1993; Morris et al., 2013).

We take a dialectic approach in reinterpreting Kant's (1790/1914) dilemma of freedom of human acting, versus a determinism approach that analyses different 'levels' of acting, i.e., praxis and poïesis belonging to the Aristotelian tradition (Aristotle, 1968). By doing so, we adopt an anthropological philosophy perspective rather than a psychological approach to describe this dichotomy. We posit that the philosophical approach towards human action, needs and behaviours engenders a different perspective for determining the appropriate scope and structure of entrepreneurship education. While it would be naïve to claim that there is a 'universally true' educational model, a model that is theoretically inferred provides guidance that is less bounded to a specific context (time and place) that may become outdated or lack relevance. Rather, our proposed model is flexible and adaptable to a variety of educational contexts, scopes and structures of a program or initiative, and changes in educational foci or areas.

The contributions of this paper to the entrepreneurship education literature are at least twofold. First, we develop a pedagogical model based on a dialectical approach to human action that describes and assesses the scope and structure of entrepreneurship education. The result is a modular approach that encompasses four educational foci (personal attitudes, meta-competencies, strategizing, organizing) and integrates the existential and pragmatic needs of potential entrepreneurs to develop their entrepreneurial attitudes and behaviours. Second, we use this classification of educational foci/areas to identify different pedagogies and approaches that would be most effective for teaching and developing entrepreneurship.

The remainder of this paper is structured as follows. We first present the philosophical foundations for creating a comprehensive entrepreneurship education model. We then relate these philosophical dimensions to the entrepreneurship education literature in respect to the scope (internal and external orientation) and structure (soft and hard and skills and knowledge) considered important for engendering entrepreneurial 
intentions (Do Paco et al., 2015). Our focus then turns to translating these philosophical insights into a conceptual model of entrepreneurship education, and developing propositions for future research. The following section identifies different pedagogies relating to each component of the entrepreneurship education model to guide its application, and then we provide summary conclusions.

\section{Philosophical bases for an entrepreneurship education model}

One of the most important problems in the entrepreneurship education literature is understanding different educational approaches and their outcomes (Nabi et al., 2017). We aim to respond to this call by developing a deductive model inferred through philosophical logic.

Many scholars have noted that 'acting' is a central element of entrepreneurship and that acting is the engine for starting and operating a business (e.g., Frese, 2009; McMullen and Shepherd, 2006; Morris et al., 2013). Acting is not merely operational execution but rather encompasses a whole process that involves both actions and cognitive elaboration about how to plan and structure such actions (Gielnik et al., 2015). Therefore, we present two dichotomies of classic Western philosophies with a focus on acting. We juxtapose an interpretation of autonomy based on Kant's (1790/1914; 2006, ed. origin. 1798) freedom vs. determinism concept with Aristotle's (1968) praxis and poïesis profiles of action (see Table 1).

Table 1 about here

One of Kant's main concerns was the analysis of human freedom (of acting) and its relative constraints, thereby providing a robust philosophical explanation of human agency. We selected Aristotle because he was the first to delve into acting in human behaviour and his profiles (or layers) of acting are still considered innovative (Ackrill, 1978; Eikeland, 2008; Jimenez, 2016). Together, these two philosophical pillars provide a strong theoretical foundation for understanding a central element of entrepreneurship, i.e., acting (McMullen and Shepherd, 2006; Morris et al., 2013). Acting is the fundamental element for developing a model of entrepreneurship education that transcends specific contingencies and contexts to delineate the 
different scopes and structures of educational initiatives.

\subsection{Dimensions of the agent: internal and external aspects influencing human acting}

Since the time of ancient Greece, philosophers have debated the question of free will. One group of scholars contend that human beings have freedom over their actions, fact that also implies responsibility (Jimenez, 2016; Meyer, 2015; Roberts, 1989). Other scholars contend that the determinism of nature mechanistically subdues the natural world (and consequently human beings) through bundled chains of cause-effect relations (e.g., O'Connor, 2000). Kant's work was deeply concerned with this controversial philosophical question (Mele, 1995); in the Critique of Pure Reason, for example, Kant (1781/1899) took a position that favoured the mechanistic structure of the world. However, in relation to the third antinomy, it is possible to see a fissure in his firm conviction about a mechanistic world (Vaida, 2009). Indeed, the antinomy states that "[Thesis]: Causality, according to the laws of nature, is not the only causality from which all the phenomena of the world can be deduced. In order to account for these phenomena it is necessary also to admit another causality, that of freedom [...] [Antithesis]: There is no freedom, but everything in the world takes place entirely according to the laws of nature." (Kant, 1781/1899, pp.448A476Bff.)

Yet in the second Critique, Kant adopts a completely different position when writing about moral and ethical behaviours guided by practical reason. Kant posits freedom as the driving force as well as the mean to the final purpose (Allison, 1990). However, this 'fracture' is possibly recomposed with Kant's final critique that clearly addresses a unifying vision of freedom and nature due to the third faculty of the human spirit, judgment (Bruno, 2010; Wood, 2003). Kant identifies two types of judgment: determinant and reflective (Kant, 1781/1899, 5: 386-389). Determinant judgement is the traditional way of judging where universal concepts are applied to the particularities of reality. Conversely, reflective judgment is the opposite process where peculiarities of reality are re-connected to universals arising from pure reason. Thus, the subjectivity of the judging agent plays a predominant role and each individual may find his/her own solution that must finally match some a priori rules, i.e. general principles (Arendt, 1958). However, reflective judgment transpires through confrontation and dialectics, and is not derived from pure rationality. 
Such judgment allows understanding reality as final despite it not being intrinsically so. Indeed, the human intellect cannot work in any other way. Sense-making is a prerequisite to understanding - even if the final purpose of things does not necessarily exist (Mele, 1995). However, this is also an expression of determinism as it is governed by the structure of human thought (Allison, 1990; Bruno, 2010; Vaida, 2009).

This free will/determinism dichotomy allows us to introduce and translate a basic form of a dualistic approach to the self of the agent. We may think about the self as a tension between autos, a representation of the desiring side of the self and expression of intellectual freedom, and nomos, a representation of the regulating side of the self and an expression of the determinism arising from nature (Mele, 1995; Wood, 2003). Taken as a whole, autos and nomos are essential functions of the self that serve as a meta-function related to managing the autonomy of a subject ((Kant, 2006, ed. origin. 1798). Typically, impulses from autos try to overcome a state of need, but at the same time, an autos without rest would lose its freedom and become a 'slave of the desire'. Having desires or having direction coming from them are insufficient conditions for emancipation which, in order to achieved, also requires correct acting and actions. Thus, if the actor does not want to fall into a pathological state, s/he needs a form of nomos to appropriately relate to the contingencies of reality. The nomos acts as a regulator of behaviours and actions, disciplining the autos and thus discovering enjoyable ways to fulfil the desire (Kant, 2006, ed. origin. 1798; Lottin, 1942). However, if a nomos is too restrictive in terms of abiding by the rules, it risks disheartening the vital 'sparks' of autos. This condition reduces the autonomy and satisfaction while depressing and annihilating the desire (Mele, 1995).

From this perspective, the self can be understood as a system that connects it to the world and other agents. This system is open as much as autos seeks satisfaction of the desire outside the self. The external orientation of autos is normal because urges of desire arise from a state of need/necessity, thus the self cannot compensate for this lack autonomously. Nevertheless, the system also needs to be closed at a certain point in order to avoid a situation in which the self gets lost in the mare magnum (vast sea) of possibilities. Indeed, nomos confers such a closure when it finds rules, laws, and instructions that can translate an ideal possibility into feasible directions. Autonomy is achieved when this system of openings/closures finds an 
idiosyncratic equilibrium suited for the contingencies of reality (Kant, 2006, ed. origin. 1798; Wood, 2003). This equilibrium directs the desire toward potentially achievable goals, further suggesting those steps needed for goal attainment.

\subsection{Profiles of action: different layers of acting}

The second dichotomy focuses on the dimensions of acting. In particular, we focus on profiles of action following the Aristotelian division of praxis and poïesis. For Aristotle, there are different types of reasoning (1968, VI, 1139a-1141a). Theoretical reasoning (theoria) relates to the intellectual virtue of episteme and nous that together represent sophia (or theoretical wisdom/reason). Non-theoretical reasoning can be practical reasoning (phronesis) applied to praxis that determines how to act morally; while technical reasoning (techne) is directed towards an external entity or production-oriented target, as in poïesis. Despite the lexical similarities of these archaic terms with those of modern languages, their meanings are actually quite different. Theoria, often translated as theory, concerns the discovery of universal or ultimate truths that are unchangeable. These inquiries are not related to theory or to its application, confirmation, or falsification as the modern world has learned to understand (Carr, 2004). Yet, in the modern and technological world, production has reached a high degree of immateriality, rendering it difficult to unambiguously differentiate between the meanings of 'doing' (usually applied in the context of praxis) and 'making' (usually referred to as poïesis). Thus, some scholars have indeed questioned the appropriateness of translating doing versus making for praxis and poïesis (Sennett, 2008; Squires, 2001, 2003).

The philosophy of education literature offers further insights in the evolution of interpretations of this dichotomy. Contrary to Aristotle, Leontjev's (1978) action model sees each action or act as an interplay of subjects, activities and objects (general outputs). Volanen (2012) interprets theoria as first thinking related to a state of being of the subject, poïesis as performance, and praxis as behaviours and related reflections. Although this latter perspective is largely shared among scholars (e.g., Broadie, 1991; Squires, 2003), in this paper, we retain the traditional praxis/poïesis dichotomy for several reasons. As identified by Kristjánsson (2005), education is more likely to directly affect behaviour (praxis) rather than 'being' (theoria). There is a lack of agreement that theoria can be translated as the self or the subject's 'being', 
with philosophy of education authors often referring to praxis as the activity of thinking that is deeply embedded with subjectivity (Dunne, 1993; Kristjánsson, 2005). For these reasons, we consider praxis as the 'highest' profile of action/acting in terms of creation of meanings.

In our view, praxis responds to questions of 'meaning' in action/acting and relates to the humanistic capacity for rational action to reach objectives. Praxis makes it possible to interpret what is experienced by the subject and thus to determine the agent's objectives and values. Similarly, consideration of poïesis as production may be reductive (Sennet, 2008; Squires, 2003). Examples of activities of poïesis that Aristotle (1968, VI, 1180b13-1181b3) cites such as medicine, sailing, and poetry are difficult to consider as being mere applications of thinking to an end. In this regard, a form of 'acquired knowledge' needs to be elaborated before being applied and this reveals a mediating process (Broadie, 1991; Peirce, 1965). Mere execution towards an end is rarely preferable, but is singularly related to the traditional concept of 'making' or poïesis. Without 'curiosity' about the 'why' of acting (praxis), the agent feels a deep sense of alienation (Sennet, 2008). These philosophers advance the idea that theoretical and practical reasoning are similar and act on abstraction (Broadie, 1991), while poietic thinking is more directed toward the concrete effects of actions and acting (Moore, 1985). Thus, in the modern world, poïesis can be understood as comprised of two levels (Arendt, 1994). The upper level is pragma which connects praxis and poïesis by partnering the logic of goals and values with the 'tools' of technical efficiency and effectiveness (Peirce, 1965). In contrast, the lower level can be regarded as 'pure poïesis' that is a function of execution generally conditioned by a restricted rationality and a given set of situations; thus this is the level where decisions are applied and it only 'operates'.

\subsection{A revised model of acting}

We utilise these philosophical dichotomies to construct a full model of acting that includes internal and external relations. This philosophical model is comprised of four quadrants: autos/praxis, nomos/praxis, autos/(pragma)poïesis, nomos/(pragma)poïesis. (see Figure 1). As previously discussed, autos, interpreted as the psychological manifestation of human freedom, is the internal drive for acting (Eysenck, 2013; Kant, 2006, ed. origin. 1798); nomos, interpreted as the psychological manifestation of 
external determinism thus is heteronomy, the perceived external pressures and constraints for acting (Kant, 2006, ed. origin. 1798; Wood, 2003). Praxis is a meaning-full level of acting, or higher profile of acting where actual effects of acting are still only in the cognitive sphere. In contrast, (pragma)poïesis is an actionfull level of acting, or a medium and lower profile of acting where the actual effects are produced in the external environment (Dunne, 1993).

Figure 1 about here

The autos/praxis quadrant is concerned with the orientation of desire. At the highest level or praxis, this orientation indicates behaviours to engage in to satisfy a desire. The consequences of such behaviours are primarily internal and directly affect the agent's personal sense of well-being. Thus, preferences are shaped with regard to goals and to the subsequent feedback from the experience of realizing goals. This represents the highest level of freedom as it allows the agent self-direction (Ackrill, 1978). In the nomos/praxis quadrant, preferred goals are emphasised along with the restrictions based on the internal structure of the agent. While the agent may have a set of preferred goals, during the selection of potential best behaviours, s/he is faced with 'restrictions' that may hinder the development of appropriate behaviours (Allison, 1990). As such, this dimension is a cognitive order accorded to a behaviour that is informed by one's ethical and character disposition. The motivation is to match one's beliefs with one's behaviours, recognizing preferred behaviours as those fitting one's self-concept.

While the autos/praxis and nomos/praxis quadrants focus on the cognitive and internal structure of acting, in order to be effective, this needs to be articulated at a more concrete level of acting within the (pragma)poïesis context. At this lower level acting of (pragma)poïesis in as much as in praxis, the agent experiences tension between goals and means. This tension produces modifications of the external world with the seeds of real actions being created at this level. The self in the autos/(pragma)poïesis quadrant translates preferred potential goals into objectives and discrete tasks. Such simple objectives can generate problems of balancing the practical coordination of sub-objectives and tasks with the need for coherent 
behaviour to attain general goals (Arendt, 1994). Finally, in the nomos/(pragma)poïesis quadrant, the self seeks resources and useful techniques to attain the overall objective. Such self-organisation involves orderly acting and efficient procedures.

In this way, it was possible to reduce strong dichotomies like those existing between praxis and poïesis, and freedom and heteronomy, respectively, as conveyed originally by Aristotle and Kant without distorting the traditional debate of these two prominent philosophers. Indeed, we have retained the original dimensions that describe both internal and external perceptions. The Aristotelian distinction is directed towards the object of action, where praxis reflexes results internally while poïesis projects them outwardly. In contrast, Kant's distinction is oriented towards the drivers of action where freedom is the result of internal forces while heteronomy is the result of external forces. This approach also allows for the concept of a connection between entrepreneurship and its educational aspects while underpinning a debate regarding the fundamental epistemology.

\section{Dimensions of entrepreneurship education}

These theoretical foundations can be used to delineate dimensions of entrepreneurship education. First, we discuss the scope of entrepreneurship education in respect to stimulating an entrepreneurial mindset/subjectivity, behaviours, and action. Second, we address the structure and contents of entrepreneurship education in terms of knowledge, skills and competencies to be developed.

\subsection{Scope of entrepreneurship education}

The scope of entrepreneurship education (Fayolle, 2013; Fayolle and Gailly, 2008; Jack and Anderson, 1999) aims to stimulate intentions to start a new venture or embark on an entrepreneurial career (Krueger and Carsrud, 1993; Sánchez, 2011). Shapero and Sokol's (1982) entrepreneurial event model explains the formation of entrepreneurial behaviour intentions (Guerrero et al., 2008; Krueger et al., 2000; Liñán, 2004, 2008), which Krueger and Brazeal (1994) further developed in their entrepreneurial potential model.

Figure 2 about here 
As shown in Figure 2, displacement precipitates a change in behaviour, leading the decision-maker to seek the best opportunities available from a set of alternatives (Katz, 1992). However, an entrepreneurial career will be pursued only if one has a propensity to act as well as perceives an opportunity to be credible (Liñán, 2004; Shapero and Sokol, 1982). The credibility of an entrepreneurial opportunity is a function of both perceived desirability and perceived feasibility. In order to choose (entrepreneurial) behaviour, one needs to feel some degree of attraction toward it, and this judgment is influenced by cultural, personal and/or experiential factors (e.g., prestige, recognition, social norms). The perception of feasibility of behaviours relates to self-efficacy, the perceived ability to execute a target behaviour (Bandura, 1986). Personal attitudes, abilities, and cognitive skills comprise the self-system which plays a major role in how one perceives a situation and subsequently responds (Bandura, 1986). Indeed, personal perceptions of selfefficacy can influence perseverance and resilience during negative performance situations, and impact overall conviction to being successful. Thus, by stimulating perceived self-efficacy, it is possible to influence the behavioural response process (Boyd and Vozikis, 1994).

Therefore, in respect to entrepreneurial intentions, the credibility of an opportunity sets the boundaries to delineate potential actions, whereas the propensity to act sets and plans favourable conditions for the actual behaviours to occur (Krueger and Brazeal, 1994). Thus, entrepreneurship education is responsible for providing students with a mental and factual propensity to be entrepreneurs (Elenurm and Heil, 2015; Guerrero et al., 2008; Liñán, 2004, 2008). In sum, the scope of entrepreneurship education is considered to be twofold; to enhance students' perceptions of credibility about an entrepreneurial career option (subjective impact), and at the same time, to stimulate students' propensity to act to reach such goals and start a new venture (objective impact) (Nabi et al., 2017).

In respect to our philosophical framework, the first scope (subjective impact) is aligned with the sphere of praxis in respect to its existential and internal nature, while the second scope (objective impact) is externally-oriented and aligned with the profile of (pragma)/poïesis acting. Further, credibility arises when entrepreneurship is perceived both as an appealing (desirability aspect) and achievable (feasibility aspect) 
behaviour/option. Desirability is a clear impulse of an autos as its expression of freedom for the agent, whereas feasibility is the foreseeable path determined by external constraints indicated by a nomos.

\subsection{Structure of entrepreneurship education}

Another relevant aspect for entrepreneurship education is to map its contents and so its structure (Fayolle, 2013). Several studies have sought to map necessary entrepreneurial and business skills and competencies that should be included in entrepreneurship curricula and pedagogies (e.g., Dana, 1987; Hood and Young, 1993; McMullan and Long 1987; Sánchez, 2011; Morris et al., 2013). From the many different classifications developed, two general categories of entrepreneurial competencies and skills have emerged: soft competencies that stimulate changes in students' mindsets to increase their propensity to act entrepreneurially (Fretschner and Weber, 2013; Liñán, 2004); and hard competencies that provide potential entrepreneurs with a set of practical skills to use in a business context. Hence, it is important to understand how the prevailing orientations in entrepreneurship education contents, pedagogies and structures may enhance students' entrepreneurial intentions.

The soft core of entrepreneurship education focuses on developing one's propensity to act entrepreneurially in recognizing and creating business opportunities (Fretschner and Weber, 2013; Liñán, 2004). Entrepreneurial action is regarded as involving a particular cognitive ability (e.g., creativity, vision, opportunistic thinking, positive thinking) and personal characteristics (e.g., self-motivation, tolerance for ambiguity, resilience, need for achievement) (Fayolle and Gally, 2015; Hood and Young, 1993). The art of entrepreneurship can be more challenging to teach (Jack and Anderson, 1999; Rae, 2005) as it involves developing intangible qualities such as attitudes, propensities, motivations, lateral and creative thinking (Kuehn, 2008; McMullan and Long, 1987; Smith et al., 2012; Vesper and McMullan, 1988). Thus, traditional teaching methods and approaches are somewhat deficient in stimulating the entrepreneurial mindset in students (Fretschner and Weber, 2013; Krueger and Carsrud, 1993; Nabi et al., 2017; Neergaard et al., 2012; Sánchez, 2011). In addition, the global financial crisis and business scandals have increased pressures on business schools to include modules in business ethics and philosophy for potential entrepreneurs (e.g., Grassl, 2010; Small, 2004; Waddock and Lozano, 2013). Studying ethics can improve 
leaders' self-awareness and sensitivity toward various stakeholders (Akrivou and Bradbury-Huang, 2015), and this is necessary for making sound judgments in complex and uncertain entrepreneurial environments (Harmeling et al., 2009; Pellegrini and Ciappei, 2015).

Instead, entrepreneurship and management education share a common background in terms of a hard core of content knowledge and practical skills necessary for managing a business (Vesper and McMullan, 1989). Business school curricula often offer courses to develop students' content knowledge of specific business related (e.g., accounting, finance, marketing, operation management, human resource management) and managerial skills (e.g., planning, communication), with the objective being to prepare students to navigate the complexity of the business world. Indeed, entrepreneurship education needs to complement practical knowledge with learning the managerial skills to effectively marshal resources for entrepreneurial success (e.g., Chang and Rieple, 2013; Chell, 2013; Morris et al., 2013). Especially for managers and entrepreneurs, learning processes seem to be much easier when the practical aspects of education can be related directly to their daily work (Brink and Madsen, 2015). Again, unfortunately even in this case, such content knowledge is often conveyed through traditional teaching methods which may constrain learning absorption (Rideout and Gray, 2013; Nabi et al., 2017; Neergaard et al., 2012). Also referred to as the science of entrepreneurial learning (Rae, 2005), this hard core of entrepreneurship should not be taken for granted nor demoted in entrepreneurship education.

\section{A comprehensive model of entrepreneurship education}

Our conceptual model of entrepreneurship education combines these scope and structure dimensions to delineate four education components: the soft core components of personal attitudes and metacompetencies; and the hard core components of strategizing and organizing. In addition, an integrative approach is depicted in respect to directions and criteria for acting which relate to both soft and hard education components. For each aspect, we discuss the philosophical linkages; mindsets, skills, and knowledge focused on; and develop theoretical propositions for entrepreneurship education research.

Figure 3 about here 


\subsection{Soft core components}

As related in the philosophical discourse, a potential satisfactory behaviour (an intended course of action) is realisd when a preferable behaviour, oriented by autos, is recognised as a viable alternative acting of nomos (Kant, 2006, ed. origin. 1798). This condition posits that entrepreneurial behaviour needs to be regarded as both desirable and feasible before it is pursued (Krueger and Brazeal, 1994; Shapero, 1982). Thus, the soft core of the entrepreneurship education is closely tied to engendering subjective perceptions of the credibility of entrepreneurship, with the aim being to promote an entrepreneurial mindset and metacompetencies (Jack and Anderson, 1999; Liñán, 2004; Nabi et al., 2017; Smith et al., 2012). The bundle of skills and approaches forming the soft core of the entrepreneurship education affects students' subjectivity, particularly in shaping and forming intentions toward behaviours, i.e., praxis-related elements. As shown in Figure 2, the two focal areas for the soft core of entrepreneurship education are personal attitudes and meta-competencies.

The personal attitudes component attends to the 'initial' inner preferences and attitudes of an agent (autos-orientation) toward a specific behaviour that is still to be manifested (praxis-located). Thus, the focus is on developing the entrepreneurial traits and characteristics associated with responsiveness to an entrepreneurial opportunity. Some entrepreneurial traits are aspirational such as needs for achievement and autonomy (Vesper and McMullan, 1988). Other personal traits such as propensity for innovativeness, nonconformity, proactiveness, and tolerance for ambiguity can be linked to the intrinsic enjoyment in discovery (Florin et al., 2007). Personal traits such as tenacity, resilience, and perseverance provide the "mental energy' to sustain and face business contingencies (Morris et al., 2013). Finally, several Big Five personality characteristics (Costa and McCrae, 1992), especially conscientiousness, openness to experience and emotional stability, are related to entrepreneurship (e.g., Zhao and Seibert, 2006).

The meta-competencies component is concerned with the opportunistic mentality that serves to translate what the individual desires into a way to achieve that desire, selecting from alternatives, and forming preferences for acting. The feasibility assessment of entrepreneurial behaviour may lead one to 
discard desirable ideas. This aspect of practical thinking that engages acting and empowerment is, in Kant's words (1959, pp. 85), “[...] is man's emergence from his self-imposed nonage. Nonage is the inability to use one's own understanding without another's guidance. This nonage is self-imposed if its cause lies not in lack of understanding but in indecision and lack of courage to use one's own mind without another's guidance". Thus, meta-competencies education seeks to develop a set of cognitive and non-cognitive metaskills to regulate (nomos-ordered) the inner preferences of the person and evaluate the consequences of such potential actions (praxis-located).

In sum, the soft core of entrepreneurship education engenders the perceived credibility of entrepreneurial behaviours. Therefore, we propose:

Proposition 1: An effective entrepreneurship education program impacts students' subjectivities(mindsets) and behaviours. This 'soft' core of entrepreneurship education seeks to modify preferences of students (desirability of entrepreneurial behaviour), as well as criteria and methods to recognise such preferences as viable and feasible. Hence, the soft core of entrepreneurship education needs to:

a. develop traits and meta-competencies related to the 'art' of entrepreneurship that can mold (desirability) and evaluate (feasibility) preferences of students

b. use pedagogies that expose students to some aspects of the entrepreneurial thinking. primarily through experiential and reflective learning.

\subsection{Hard core components}

The hard core of entrepreneurship education develops practice-oriented knowledge and skills to pursue entrepreneurial opportunities. The structure of this aspect of entrepreneurship education has more objective contents and is action-oriented (Gielnik et al., 2015; Tan and Ng, 2006), which relates to pragma and poïesis that foster acting and translate what has been set at the level of praxis into concrete actions (Pierce, 1965). This process reduces abstract ideas, dispositions and preferences into objectives for action as well as feasible action plans. In doing so, this process provides an orientation for acting and a searching for means to reach such objectives that brings order to acting. Thus, the hard core of the entrepreneurship education 
focuses on developing skills that encourage students' propensity to pursue opportunities and take action (Krueger and Brazeal, 1994).

Strategizing is an entrepreneurial process that translates chosen preferences into the seeds of action/acting to attain concrete outcomes. The strategizing component focuses on developing action plans to implement opportunities viewed to be credible. The orientation is toward acting (and not only the subjectivity of the agent) and the meaning and value created are for the entrepreneurial venture and markets (pragma/poïesis-located) rather than for the individual person (praxis-orientation). Strategizing involves planning (Frese, 2009) while also being flexible and adaptable to the pressures of external environments (Morris et al., 2013), as well as levering and bootstrapping scarce resources (Chang and Rieple, 2013; Gaglio and Katz, 2001). Strategizing actions include strategic analysis and decision making (Collins et al., 2006; McMullan and Long, 1987), networking to attract investors and engage with stakeholders (Chell, 2003; Hood and Young, 1993), and using a risk mitigation process to assess available resources and capabilities (Sánchez, 2011).

The organizing component relates to the most technical competencies of entrepreneurship or small business management (Fayolle and Gailly, 2008; Hytti and O'Gorman, 2004; Gorman et al., 1997; Jack and Anderson, 1999). Although still concerned with an action-full domain (pragma/poïesis-located), organizing education seeks to regulate action in order to achieve set objectives, i.e., criteria for action/acting (nomosordered). This set of management knowledge and skills includes: accounting, budgeting, financial and cash management, prototyping process knowledge, organisation and coordination of work, resource allocation, and marketing (Brink and Madsen, 2015; Chell, 2013; Colombo and Grilli, 2005; Thursby et al., 2009). Further, organizing skills and knowledge should be consistent with developing what Morris et al. (2013) defined as guerrilla skills, i.e., the ability to take advantage of external surroundings and network to perform everyday tasks in an efficient and coherent way.

In sum, the hard core of entrepreneurship education engenders (pragma)/poïesis, a propensity to act. Therefore, we propose:

Proposition 2: An effective entrepreneurship education program impacts students' ability to pursue 
concrete actions. This 'hard' core of entrepreneurship education seeks to define strategies as the orientation and objectives for acting, as well as to organise methods, resources and means to attain such objectives. Hence, the hard core of entrepreneurship education needs to:

a. develop a bundle of knowledge and skills related to the 'science' of entrepreneurship that can form/direct (strategizing) and evaluate/structure (organizing) entrepreneurial action.

b. use a bundle of pedagogies primarily related to action learning.

\subsection{Integrative approach}

Given the identified need to develop both entrepreneurial preferences and actions, entrepreneurial education should focus on both the soft and hard cores of entrepreneurship (e.g., Chang and Rieple, 2013; Gielnik et al., 2015; Muñoz et al., 2011; Rideout and Gray, 2013; Tan and Ng, 2006). Entrepreneurial intention models (Guerrero et al., 2008; Krueger and Brazeal, 1994; Shapero and Sokol, 1982) also suggest that entrepreneurship education structures need to increase the appeal of such behaviours through inspirational role modelling and exposure to entrepreneurial contexts (Bechard and Gregoire, 2007; Smith et al., 2012). Similarly, students' perceived self-efficacy to be successful entrepreneurs can be enhanced by introductions to concrete experiences of entrepreneurial life (Kuehn, 2008; Morris et al., 2012). Whereas both elements are related to the soft core of entrepreneurship education (Fayolle and Gally, 2008), hard core business knowledge and skills are also necessary to successfully set up and manage entrepreneurial ventures (Brink and Madsen, 2015; Honig, 2004; Loué and Baronet, 2012; Rae, 2005). As such, the structure of entrepreneurship education should address the full set of aspects relating to inner motivations (praxis-located) and acting approaches (pragma/poïesis-located), as well as being both self-stimulated (autos-domain) and correctly directed (nomos-domain).

In sum, a comprehensive approach to entrepreneurial education necessitates a focus on acting (McMullen and Shepherd, 2006; Morris et al., 2013), both in the formation of behaviours (soft core) and concrete action (hard core) (Gielnik et al., 2015). Thus, entrepreneurship education should have a balanced nature that mediates between these two elements (Kristjánsson, 2005); the hard core of entrepreneurship education as pragma/poïesis (Squires, 2001), that is oriented by soft skills to form entrepreneurial 
experience as praxis (Dunne, 1993). Therefore, we propose:

Proposition 3: An effective entrepreneurship education program aims to affect subjectivity(mindsets), behaviours, and action. Hence, entrepreneurship education needs to:

a. act upon both the 'art' and 'science' of entrepreneurship by modifying preferences and criteria for behaviours as well as defining strategies and organisation for acting.

b. use pedagogies that blend experiential, reflective and action learning or what has been defined as 'live learning'.

\section{$5 \quad$ Mapping entrepreneurship education pedagogies}

This entrepreneurship education model can be used to inform the assessment and development of entrepreneurship education programs and courses. We reviewed the entrepreneurship education literature to identify pedagogies and approaches that would be most effective for each facet of student entrepreneurial development. In mapping pedagogies, we included only the most innovative approaches for entrepreneurship education rather than traditional approaches that are regarded as less effective (e.g., Bechard and Gregoire, 2007; Neergaard et al., 2012). Thus, we do not include traditional lectures (Hytti and O'Gorman, 2004 Muñoz et al., 2011), and specific for entrepreneurship modules, business plan creation exercises (Brink and Madsen, 2015; Tan and Ng, 2006; Tounés et al., 2014). Although still widely used, we argue that traditional pedagogies need to be integrated with experiential and action-oriented pedagogies in entrepreneurship education (Morris et al., 2012).

For the soft core of entrepreneurship education, we identity pedagogies for developing personal attitudes (praxis-orienting), meta-competencies (praxis-ordering), and integrative soft core pedagogies. For the hard core of entrepreneurship education, we identity pedagogies for developing strategizing (pragma/poïesis-orienting), organizing (pragma/poïesis-ordering). and integrative hard core pedagogies.

We also present comprehensive pedagogies that take a holistic approach to entrepreneurship development. Table 2 summarises the mapping of pedagogies based on our model of entrepreneurship education.

Table 2 about here 


\subsection{Soft core pedagogies: personal attitudes}

Personal attitudes development is concerned with individual differences in personal traits, values, motivations, and ways of approaching and adjusting to the external environment (Eysenck, 2013). This education area is focused on developing an entrepreneurial aptitude, driving force and curiosity for creating something new (Muñoz et al., 2011).

In the debate about traditional entrepreneurship education and its limited effectiveness in stimulating such personal and attitudinal changes (Kuratko, 2005), a more holistic approach to entrepreneurship education has been advocated (Fayolle and Gally, 2008, 2015; Jack and Anderson, 1999; Nabi et al., 2017). In particular, experiential learning and direct contact with entrepreneurs and entrepreneurial life can enhance self-awareness and prompt personal change in the entrepreneurial mindset of students (e.g., Boyatzis, 1982; Gondim and Mutti, 2011; Harmeling et al., 2009; Spencer and Spencer, 1993).

As shown in Table 2, specific methods for experiential learning include: contact with mentors and entrepreneurs (Burrows and Wragge, 2013; Watts and Wray, 2012); telling stories of successful entrepreneurs' life experiences (Boyd and Vozikis, 1994; Eriksson, 2003; Morris et al., 2012) that may awaken students' hidden motivation and aspirations (Rae, 2005); and visits and field trips to entrepreneurial firms (Hood and Young, 1993; Hytti and O'Gorman, 2004). Another effective approach is promoting innovative responses by students whether through formal assignments (e.g., extra-points for originality, innovativeness), encouraging engagement in extra curriculum activities (Florin et al., 2007), with possibly monetary incentives for entrepreneurial activities (Jones and Jones, 2011).

In sum, these teaching methods can help students in the process of emancipation, finding a reason to be entrepreneurs, reshaping their behaviours, and becoming familiar with the rewards and stresses of entrepreneurial life (Gondim and Mutti, 2011).

\subsection{Soft core pedagogies: meta-competencies}

Meta-competencies are the inner base for selecting and evaluating entrepreneurial behaviours consistent with personal preferences and values (Hytti and O'Gorman, 2004). Meta-competencies 
education aims to develop students' abilities to practise creativity and divergent thinking (Armstrong, 2014; DeTienne and Chandler, 2004; Muñoz et al., 2011; Smith et al., 2012), recognise and evaluate opportunities (Gaglio and Katz, 2001; Morris et al., 2013), and to feel confident about pursuing such opportunities and, i.e., self-efficacy and calculated risk taking (Krueger et al., 2000; Kuehn, 2008). Another focus of metacompetency education is developing the leadership,emotional intelligence, and interpersonal skills for effectively managing relationships with external and internal stakeholders (Çakir and Kunday, 2017; Chell, 2013; Collins et al., 2006; Garalis and Strazdienè, 2007; Man et al., 2002; Omrane, 2015) with ethical sensitivity (Harmeling et al., 2009; Pellegrini and Ciappei, 2015; Small, 2004).

Traditional pedagogies are ill-suited for learning the 'art' of entrepreneurship meta-competencies (Fayolle and Gally, 2015; Hytti and O’Gorman, 2004 Muñoz et al., 2011; Nabi et al., 2017; Neergaard et al., 2012). Instead, meta-competencies education should emphasise experiential learning to develop selfefficacy toward entrepreneurial activities. Such approaches would encourage students to 'experiment' with mental approaches and aspects of entrepreneurial life (Gielnik et al., 2015; Gilbert, 2012; Morris et al., 2012; Smith et al., 2012; Tan and Ng, 2006). Example pedagogies include students' presentation of their work to external judges or panels (Chang, Benamraoui and Rieple, 2014; Smith et al., 2012) as well as simulation and business games (Garalis and Strazdienè, 2007; Honig, 2004; Vorley and Williams, 2016; Watts and Wray, 2012). Another set of pedagogies focus on directly stimulating the soft skills that are the bases for intended entrepreneurial behaviours, such as creativity and opportunity discovery exercises (Burrows and Wragge, 2013). Also, DeTienne and Chandler (2004) showed positive results with the use of the SEEC training (securing, expanding, exposing, and challenging) in the form of creativity diaries. Similar results have been found for other techniques such as SCAMPER (substitute, combine, adapt, magnify/modify, put to other uses, eliminate, and reverse/rearrange) and idea grids (Gudry et al., 2014).

\subsection{Soft core pedagogies: integrative}

The soft core of entrepreneurship education focuses on intangible elements related to the personal sphere of the individual. Although some pedagogies are more relevant for orienting (personal attitudes) or

ordering/selecting (meta-competencies) preferences, others can address both aspects. For instance, 
reflective thinking on acting and focusing on the learner and his/her needs (Kolb and Kolb, 2005) is a central element in both educational areas. As such, students should be actively exposed to and gain confidence with aspects of entrepreneurial life, especially mental approaches and schemata. However, becoming aware of the meaning of those experiences is the true key for stimulating the art of entrepreneurship (Chang et al., 2014; Florin et al., 2007; Fretschner and Weber, 2013). This can be achieved through self-reflection assignments about entrepreneurial projects and business plans in terms of personal or career development (Gondim and Mutti, 2011; Kirkwood et al., 2014); or through analyses of prior experience with the new knowledge/skills, e.g., an entrepreneurial repertory grid analysis of one's personal/working network (Klapper, 2014).

Other sources for reflective feedback include: mentors, such as teachers, entrepreneurs, managers in innovation centres or incubators (Florin et al., 2007; Gilbert, 2012; Kuehn, 2008); peers in student/alumni networks (e.g., Pittaway et al., 2015; Watts and Wray, 2012); external agents in entrepreneurial activities, e.g., simulation of trading activities (Jones and Jones, 2011), running a fundraising event (Chang et al., 2014). While these activities/projects impact only on praxis, their limited scope enables students to increase their confidence and practise entrepreneurial thinking but without the stress and acting of a fully entrepreneurial experience.

\subsection{Hard core pedagogies: strategizing}

Strategizing pedagogies that emphasise action-oriented learning provide opportunities for students to act as entrepreneurs in a realistic way (Gielnik et al., 2015; Gilbert, 2012; Harms, 2015). The focus is on developing a bundle of competencies, knowledge and skills that are more practical oriented and represent the science of entrepreneurship to 'navigate' the business world. While entrepreneurship education programs usually address planning and modelling skill development using traditional pedagogies, more impactful action learning approaches are less common (Brink and Madsen, 2015; De Faoite et al., 2004). These pedagogies include: student co-learning with nascent entrepreneurs who may have concrete start-up problems to be solved (Collins et al., 2006); flexible tools for planning and business modelling that can be used in real contexts (Osterwalder and Pigneur, 2010); and more interactive and innovative approaches to 
business design (Brink and Madsen, 2015; De Faoite et al., 2004; Dominguinhos and Carvalho, 2009; Tan and $\mathrm{Ng}, 2006)$.

\subsection{Hard core pedagogies: organizing}

Although this educational area is closely related to general management education, the main difference lies in the objectives. Organizing skills and knowledge should related to the initial or start-up phase (Bechard and Gregoire, 2007), or be action-oriented for implementation (Brink and Madsen, 2015; Gielnik et al., 2015; Osterwalder and Pigneur, 2010). For example, learning about cash flow concepts should also focus on cash tensions that may occur in the start-up phase and initial investment-prototyping-first sell (Thursby et al., 2009); while it is important to know legal frameworks and specific recruiting techniques for human resource management (Dominguinhos and Carvalho, 2009).

As previously identified, one limitation of entrepreneurial education has been heavy reliance on general modules on ways to organise (Dominguinhos and Carvalho, 2009; De Faoite et al., 2004). More traditional pedagogies are often used to teach such codified knowledge as well as the conceptual and technical tools to execute business strategy. Instead, more effective pedagogical approaches focus directly on students' working experience either in internships (not limited to start-ups) (Dobratz et al., 2015; Hytti and O'Gorman, 2004; Omazić and Vlahov, 2011) or bringing to class the actual problems of organisations in which participants are currently working (Brink and Madsen, 2015). In terms of codified knowledge, the emphasis should be on small business management, e.g., financial knowledge about funds, logistic and facility solutions for start-ups (Dominguinhos and Carvalho, 2009; De Faoite et al., 2004).

\subsection{Hard core pedagogies: integrative}

For both strategizing and organizing, multi-faceted action learning pedagogies are effective in developing students' action orientation (Brink and Madsen, 2015; Harms, 2015) and action knowledge (Gielnik et al., 2015). Example pedagogies include implementing entrepreneurial projects during programs (Brink and Madsen, 2015; Galloway et al., 2005; Hytti and O'Gorman, 2004), and participating in entrepreneurial events such as fairs and competitions (Chang et al., 2014; Burrows and Wragg, 2013; Smith et al., 2012). In addition, work-based learning in entrepreneurship related contexts (e.g., innovation centres 
or incubators) as well as in start-ups promotes an action-oriented approach to market opportunities and learning criteria to structure an entrepreneurial action (Dobratz et al., 2015; Gilbert, 2012; Hytti and O'Gorman, 2004; Thursby et al., 2009). All these pedagogies aim to stimulate students' ability to effectively plan and execute entrepreneurial action (Hood and Young, 1993; Morris et al., 2013).

\subsection{Comprehensive pedagogies}

There are comprehensive pedagogies that combine experiential, reflective and action learning elements to develop subjectivity and mindsets (subjective impact of entrepreneurship education) and propensity to act, and thus possibly the creation of new venture (objective impact of entrepreneurship education) (Nabi et al., 2017). Most effective is developing real projects or working on real entrepreneurial problems/projects (action learning) alongside entrepreneurs and other agents who can offer experience (experiential learning) and feedback (reflective learning) (Chang and Rieple, 2013; Chang et al., 2014; Collins et al., 2006; Gilbert, 2012; Hytti and O'Gorman, 2004; Pittaway et al., 2015; Smith et al., 2012; Thursby et al., 2009). At the same time, students engage in 'live learning', that is, experience and act in entrepreneurial ways with the support of an educational infrastructure that helps generate sense of that acting (Kuehn, 2008; Muñoz et al., 2011; Tan and $\mathrm{Ng}, 2006)$.

\section{Conclusion}

Does a general model for entrepreneurship education exist? Our intent was to stimulate reflection on how philosophical thought could contribute to the conceptualization and practice of entrepreneurship education. To do so, we proposed a reinterpretation of two different philosophical theories: Kant's (1790/1914) dichotomy of freedom vs. determinism; and Aristotle's (1968) profile of praxis and poïesis (Aristotle, 1968).

We argue that an entrepreneurship education program should affect the subjectivity, behaviours, and actions of students. Hence, it is necessary to teach both the 'art' and the 'science' of entrepreneurship (Fayolle and Gailly, 2008; Jack and Andersen, 1999). Our entrepreneurship education model incorporates both the existential (personal attitudes and meta-competencies) and pragmatic (strategizing and organizing) 
developmental needs of individuals to become entrepreneurs. In terms of structure, whereas the soft core forms the intended behaviour (selected preference), the hard core supports effective implementation of intended actions. This, harmonises into action all other aspects ensuring that action is more than simple execution, because the propensity to act is also dealing with the contingencies of the entrepreneurial world. As such, our model provides a theoretical explanation for the effectiveness of comprehensive pedagogies (e.g., Chang et al., 2014; Gielnik et al., 2015) that integratively attend to the full complement of students' entrepreneurial developmental needs.

This comprehensive model of entrepreneurship education can be used by curricula developers and teachers to assess and develop their entrepreneurship programs, courses, and pedagogical approaches. While the relative emphasis on each educational component may differ depending on program and course learning goals, the model provides a conceptual framework for this evaluation process as well as guidance and ideas for development.

For instance, to address a need for a more subjective impact on changing mindsets and behaviours, the program/module should address the soft core of entrepreneurship education (Fayolle and Gailly, 2008). This means targeting the development of personal attitudes that can shape preferences toward entrepreneurial activities (desirability) and meta-competencies to perceive such preferences as feasible (credibility) (Krueger and Brazeal 1994). In this way, the entrepreneurship education program will focus on the development of a forma mentis about how to be and think entrepreneurially. To address a need for a more objective impact, programs and modules should accord a greater emphasis on the hard core of entrepreneurship education (Brink and Madsen, 2015; Harms, 2015). The development of strategizing and organizing skills and action-knowledge will advance strategic directions and efficient criteria for implementation of entrepreneurial ventures. Thus, the program will focus on engendering a pragmatic approach to action/acting, a "forma agendi" for students to learn how to act entrepreneurially.

In respect to theoretical contribution, our model may open a new discussion in the entrepreneurship education literature about scopes and structures. We agree with Nabi et al. (2017) that entrepreneurship education scholars need to clearly define the type of impact (subjective or objective) that is being focused 
on in order to minimise conflicting findings. We also advance that the type of structure (soft and hard core) can be another differentiating element for studying entrepreneurship education interventions.

A deductively derived entrepreneurship education model based on philosophical arguments may be viewed as a limitation. However, this theoretical framework can inform empirical studies on the impacts of entrepreneurship education (e.g., Nabi et al., 2017). As we have identified, there are multi-scope impacts (Gielnik et al., 2015; Tan and Ng, 2006; Thursby et al., 2009) and hybrid pedagogical approaches (Bechard and Gregoire, 2007) that should be considered. Hence, research on entrepreneurship education needs to take a holistic multi-dimensional approach, as challenging as this may be. 


\section{REFERENCES}

Abaho, E., Olomi, D. R. and Urassa, G. C. (2015) 'Students' entrepreneurial self-efficacy: does the teaching method matter?’ Education + Training, Vol. 57, No. 8/9, pp.908-923.

Ackrill, J. L. (1978) ‘Aristotle on action’, Mind, Vol. 87, No. 4, pp.595-601.

Akrivou, K. and Bradbury-Huang, H. (2015) 'Educating integrated catalysts: transforming business schools toward ethics and sustainability', Academy of Management Learning \& Education, Vol. 14(2, pp.222-240.

Allison H. (1990) Kant's Theory of Freedom, Cambridge University Press, Cambridge, UK.

Arendt, H. (1958) The Human Condition, The University of Chicago Press, Chicago, IL.

Arendt, H. (1994) Essays in Understanding 1930-1954, Harcourt Brace, New York, NY.

Aristotle. (1968) Nicomachean Ethics (trans. H. Rackham), Harvard University Press, Cambridge, MA.

Armstrong, C. E. (2014) 'I meant to do that! Manipulating entrepreneurial intentions through the power of simple plans', Journal of Small Business and Enterprise Development, Vol. 21, No. 4, pp.638-652.

Bandura, A. (1986) The Social Foundations of Thought and Action, Prentice-Hall, Englewood Cliffs, NJ.

Bechard, J. P. and Gregoire, D. (2007) 'Archetypes of pedagogical innovation for entrepreneurship education: model and illustrations', in Fayolle, A. (Ed.): Handbook of Research in Entrepreneurship Education, Vol.1, pp.261-284, Edward Elgar Publishing, Cheltenham, UK.

Boyatzis, R.E. (1982) The Competent Manager: A Guide for Effective Management, Wiley, New York, NY.

Boyd, N.G. and Vozikis, G.S. (1994) 'The influence of self-efficacy on the development of entrepreneurial intentions and actions', Entrepreneurship Theory and Practice, Vol. 18, No. 1, pp.63-77.

Brink, T. and Madsen, S. O. (2015) 'Entrepreneurial learning requires action on the meaning generated', International Journal of Entrepreneurial Behavior \& Research, Vol. 21, No. 5, pp.650-672.

Broadie, S. (1991) Ethics with Aristotle, Oxford University Press, Oxford, UK.

Bruno P.W. (2010) Kant's Concept of Genius. Its Origin and Function in the Third Critique, Continuum International Publishing Group, London, UK.

Burrows T. and Wragg, N. (2013) 'Introducing enterprise research into the practical aspects of introducing innovative enterprise schemes as extra curricula activities in higher education', Higher Education, Skills and Work-based Learning, Vol. 3, No. 3, pp.168-179.

Buzan, T. and Buzan, B. (1996) The Mind Map Book, Plume (Penguin) Publishers, New York, NY.

Çakir, C. and Kunday, O. (2017) 'Young people's emotional intelligence promoting entrepreneurial orientation: enhanced by education', International Journal of Entrepreneurship and Small Business, Vol. 30, No. 3, pp.341-356.

Carr, W. (2004) 'Philosophy and education', Journal of Philosophy of Education, Vol. 38, No. 1, pp.5573.

Chang, J. Y. C., Benamraoui, A. and Rieple A. (2014) 'Stimulating learning about social entrepreneurship through income generation projects', International Journal of Entrepreneurial Behavior \& Research, Vol. 20, No. 5, pp.417-437.

Chang, J. and Rieple, A. (2013) 'Assessing students' entrepreneurial skills development in live projects', 
Journal of Small Business and Enterprise Development, Vol. 20, No. 1, pp.225-241.

Chell, E. (2013) 'Review of skill and the entrepreneurial process', International Journal of Entrepreneurial Behavior \& Research, Vol. 19, No. 1, pp.6-31.

Chen, S. C., Hsiao, H. C., Chang, J. C., Chou, C. M., Chen, C. P. and Shen, C. H. (2015) 'Can the entrepreneurship course improve the entrepreneurial intentions of students?', International Entrepreneurship and Management Journal, Vol. 11, No. 3), 557-569.

Collins, L. A., Smith, A. J. and Hannon P. D. (2006) 'Discovering entrepreneurship', Journal of European Industrial Training, Vol. 30, No. 3, pp.188-205.

Colombo, M. G. and Grilli, L. (2005) 'Founders' human capital and the growth of new technology-based firms: a competence-based view’, Research Policy, Vol. 34, No. 6, pp.795-816.

Costa, P. T. and McCrae, R. R. (1992) 'Four ways five factors are basic', Personality and Individual Differences, Vol. 13, No. 6, pp.653-665.

Dana, L. P. (1987). Towards a skills model for entrepreneurs. Journal of Small Business \& Entrepreneurship, 5(1), 27-31.

Dana, L. P. (1992). Entrepreneurial education in Europe. Journal of Education for Business, 68(2), 74-78.

Dana, L. Paul (2001). The education and training of entrepreneurs in Asia. Education+ Training, 43(8), 405-416.

De Faoite, D., Henry, C., Johnston K. and Van der Sijde, P. (2004) 'Entrepreneurs' attitudes to training and support initiatives: evidence from Ireland and The Netherlands', Journal of Small Business and Enterprise Development, Vol. 11, No. 4, pp.440-448.

DeTienne, D. R. and Chandler, G. N. (2004) 'Opportunity identification and its role in the entrepreneurial classroom: a pedagogical approach and empirical test', Academy of Management Learning \& Education, Vol. 3, No. 3, pp.242-257.

Dobratz, C.L., Singh, R.P. and Abbey, A. (2015) 'Using formal internships to improve entrepreneurship education programs', Journal of Entrepreneurship Education, Vol. 16, No. 1, pp.96-110.

Dominguinhos P. M. C. and Carvalho, L. M. C. (2009) 'Promoting business creation through real world experience', Education + Training, Vol. 51, No. 2, pp.150-169.

Do Paço, A., Ferreira, J. M., Raposo, M., Rodrigues, R. G. and Dinis, A. (2015) 'Entrepreneurial intentions: is education enough?', International Entrepreneurship and Management Journal, Vol. 11, No. 1, pp.57-75.

Dunne, J. (1993) Back to the Rough Ground: 'Phronesis' and 'Techne' in Modern Philosophy and in Aristotle, University of Notre Dame Press, Notre Dame, IN.

Eikeland, O. (2008) The Ways of Aristotle: Aristotelian Phronesis, Aristotelian Philosophy of Dialogue, and Action Research, Vol. 5, Peter Lang, New York, NY.

Elenurm, T. and Heil, P. (2015) 'Education and other competency sources for financially successful entrepreneurship', International Journal of Entrepreneurship and Small Business, vol. 25, No. 3, pp.314-330.

Eriksson, T. (2003) 'Towards a taxonomy of entrepreneurial learning experiences among potential entrepreneurs', Journal of Small Business and Enterprise Development, Vol. 10, No. 1, pp.106-112.

Eysenck, H. J. (2013) The Structure of Human Personality, Routledge, London, UK.

Fayolle, A. (2008) 'Entrepreneurship education at a crossroads: towards a more mature teaching field', Journal of Enterprising Culture, Vol. 16, No. 4, pp.325-337. 
Fayolle, A. (2013) 'Personal views on the future of entrepreneurship education', Entrepreneurship \& Regional Development, Vol. 25, No. 7-8, pp.692-701.

Fayolle, A. and Gailly, B. (2008) 'From craft to science: teaching models and learning processes in entrepreneurship education', Journal of European Industrial Training, Vol. 32, No. 7, pp.569-593.

Fayolle, A. and Gailly, B. (2015) 'The impact of entrepreneurship education on entrepreneurial attitudes and intention: hysteresis and persistence', Journal of Small Business Management, Vol. 53, No. 1, pp.75-93.

Florin, J., Karri, R. and Rossiter, N. (2007) 'Fostering entrepreneurial drive in business education: an attitudinal approach', Journal of Management Education, Vol. 31, No. 1, pp.17-42.

Frese, M. (2009) 'Toward a psychology of entrepreneurship: an action theory perspective', Foundations and Trends in Entrepreneurship, Vol. 5, No. 6, pp.437-496.

Fretschner, M. and Weber, S. (2013) 'Measuring and understanding the effects of entrepreneurial awareness education', Journal of Small Business Management, Vol. 51, No. 3, pp.410-428.

Gaglio, C.M. and Katz, J.A. (2001) 'The psychological basis of opportunity identification: entrepreneurial alertness', Small Business Economics, Vol. 16, No. 2, pp.95-111.

Galloway, L., Anderson, M., Brown, W. and Wilson, L. (2005) 'Enterprise skills for the economy', Education + Training, Vol. 47, No. 1, pp.7-17.

Garalis, A. and Strazdienè, G. (2007) 'Entrepreneurial skills development via simulation business enterprise', Socialiniai tyrimai, Vol. 2, No. 10, pp.39-48.

GEM (2014) Global Entrepreneurship Monitor 2014 Global Report, Kauffman Foundation, Kansas City, MO.

Gielnik, M. M., Frese, M., Kahara-Kawuki, A., Katono, I. W., Kyejjusa, S., Ngoma, M., Munene, J., Namatovu-Dawa, R., Nansubuga, F., Orobia, L., Oyugi, J., Sejjaaka, S., Sserwanga, A., Walter, T., Bischoff, K., M. and Dlugosch, T. J. (2015) 'Action and action-regulation in entrepreneurship: evaluating a student training for promoting entrepreneurship', Academy of Management Learning \& Education, Vol. 14, No. 1, pp.69-94.

Gilbert, D. H. (2012) 'From chalk and talk to walking the walk', Education + Training, Vol. 54, No. 2/3, pp.152-166.

Gondim, S. M. G. and Mutti C. (2011) 'Affections in learning situations: a study of an entrepreneurship skills development course', Journal of Workplace Learning, Vol. 23, No. 3, pp.195-208.

Gorman, G., Hanlon, D. and King, W. (1997) 'Some research perspectives on entrepreneurial education, enterprise education and education for small business management: a ten year review', International Small Business Journal, Vol. 15, No. 3, pp.56-77.

Grassl, W. (2010) 'Aquinas on management and its development', Journal of Management Development, Vol. 29, No. 7/8, pp.706-715.

Gundry, L. K., Ofstein, L. F. and Kickul, J. R. (2014) 'Seeing around corners: how creativity skills in entrepreneurship education influence innovation in business', International Journal of Management Education, Vol. 12, No. 3, pp.529-538.

Guerrero, M., Rialp, J. and Urbano, D. (2008) 'The impact of desirability and feasibility on entrepreneurial intentions: a structural equation model', International Entrepreneurship and Management Journal, Vol. 4, No. 1, pp.35-50.

Harms, R. (2015) 'Self-regulated learning, team learning and project performance in entrepreneurship education: learning in a lean startup environment', Technological Forecasting \& Social Change, 
Vol. 100, pp.21-28.

Harmeling, S.S., Sarasvathy, S.D. and Freeman, R.E. (2009) 'Related debates in ethics and entrepreneurship: values, opportunity and contingency’, Journal of Business Ethics, Vol. 84, No. 3, pp.341-365.

Honig, B. (2004) 'Entrepreneurship education: toward a model of contingency-based business planning', Academy of Management Learning \& Education, Vol. 39, No. 3, pp.258-273.

Hytti, U. and O'Gorman, C. (2004) 'What is "enterprise education”? An analysis of the objectives and methods of enterprise education programmes in four European countries', Education+ Training, Vol. 46, No. 1, pp.11-23.

Hood, J.N. and Young, J.E. (1993) 'Entrepreneurship's requisite areas of development: a survey of top executives in successful entrepreneurial firms', Journal of Business Venturing, Vol. 8, No. 2, pp.115135.

Jack, S. L. and Anderson, A. R. (1999) 'Entrepreneurship education within the enterprise culture: producing reflective practitioners', International Journal of Entrepreneurial Behavior \& Research, Vol. 5, No. 3, pp.110-125.

Jimenez, M. (2016) 'Aristotle on becoming virtuous by doing virtuous actions', Phronesis, Vol. 61, No. 1, pp.3-32.

Jones, A. and Jones. P. (2011) 'Making an impact: a profile of a business planning competition in a university’, Education+Training, Vol. 53, No. 8/9, pp.704-721.

Kant, I. (1781/1899) Critique of Pure Reason (trans. J.M.D. Meiklejohn), Wiley, New York, NY.

Kant, I. (1790/1914) Critique of Judgement (trans. J. H. Bernard), MacMillan, London, UK.

Kant, I. (1959) Foundations of the Metaphysics of Morals: What is Enlightenment?, Liberal Arts Press, New York, NY.

Kant, I. (2006) Kant: Anthropology from a Pragmatic Point of View (ed. origin, 1798), Cambridge University Press, Cambridge, UK.

Katz, J. A. (1992) 'Modeling entrepreneurial career progressions: concepts and considerations', Entrepreneurship Theory and Practice, Vol. 19, No. 2, pp.23-39.

Kirkwood, J., Dwyer, K. and Gray B. (2014) 'Students' reflections on the value of an entrepreneurship education', International Journal of Management Education, Vol. 12, No. 3, pp.307-316.

Klapper, R. G. (2014) 'A role for George Kelly's repertory grids in entrepreneurship education? Evidence from the French and Polish context', International Journal of Management Education, Vol. 12, No. 3, pp.407-421.

Kolb A. Y. and Kolb, D. A. (2005) 'Learning styles and learning spaces: enhancing experiential learning in higher education', Academy of Management Learning \& Education, Vol. 4, No. 2, pp.193-212.

Kristjánsson, K. (2005) 'Smoothing it: some Aristotelian misgivings about the phronesis-praxis perspective on education', Educational Philosophy and Theory, Vol. 37, No. 4, pp.455-473.

Krueger, N.F. and Brazeal, D.V. (1994) 'Entrepreneurial potential and potential entrepreneurs', Entrepreneurship Theory and Practice, Vol. 19, No. 3, pp.91-104.

Krueger, N.F. and Carsrud, A.L. (1993) 'Entrepreneurial intentions: applying the theory of planned behavior', Entrepreneurship and Regional Development, Vol. 5, No. 4, pp.315-330.

Krueger, N.F., Reilly, M.D. and Carsrud, A.L. (2000) 'Competing models of entrepreneurial intentions', Journal of Business Venturing, Vol. 15, No. 5/6, pp.411-432. 
Kuehn, K. W. (2008) 'Entrepreneurial intentions research: Implications for entrepreneurship education', Journal of Entrepreneurship Education, Vol. 11, pp.87-98.

Kuratko, F. D. (2005) 'The emergence of entrepreneurship education: development, trends, and challenges', Entrepreneurship Theory and Practice, Vol. 29, No. 5, pp.577-598.

Lee, S. M., Chang, D. and Lim, S. B. (2005) 'Impact of entrepreneurship education: a comparative study of the US and Korea', The International Entrepreneurship and Management Journal, Vol. 1, No. 1, pp.27-43.

Leontjev A. N. (1978) Activity, Consciousness, and Personality, Prentice-Hall, Englewood Cliffs, NJ.

Liñán, F. (2004) 'Intention-based models of entrepreneurship education', Piccolla Impresa/Small Business, Vol. 3, pp.11-35.

Liñán, F. (2008) 'Skill and value perceptions: how do they affect entrepreneurial intentions?', International Entrepreneurship and Management Journal, Vol. 4, No. 3, pp.257-272.

Liñán, F., Rodríguez-Cohard, J. C. and Rueda-Cantuche, J. M. (2011) 'Factors affecting entrepreneurial intention levels: a role for education', International Entrepreneurship and Management Journal, Vol. 7, No. 2, pp.195-218.

Lottin, O. (1942) Psychologie et Morale aux XIIe et XIIIe Siècles. Tome I: Problèmes de Psychologie, Abbaye du Mont César, Louvain, BE.

Loué, C. and Baronet, J. (2012) 'Toward a new entrepreneurial skills and competencies framework: a qualitative and quantitative study', International Journal of Entrepreneurship and Small Business, Vol. 17, No. 4, pp.455-477.

Man, T. W., Lau, T. and Chan, K. F. (2002) 'The competitiveness of small and medium enterprises: a conceptualization with focus on entrepreneurial competencies', Journal of Business Venturing, Vol. 17, No. 2, pp.123-142.

McMullan, W. and Long, W.A. (1987) 'Entrepreneurship education in the nineties', Journal of Business Venturing, Vol. 2, No. 3, pp.261-275.

McMullen, J. S. and Shepherd, D. A. (2006) 'Entrepreneurial action and the role of uncertainty in the theory of the entrepreneur', Academy of Management Review, Vol. 31, No. 1, pp.132-152.

Mele, A. (1995) Autonomous Agents, Oxford University Press, New York, NY.

Meyer, S. S. (2015) 'Aristotle's ethics and moral responsibility', Philosophical Review, Vol. 124, No. 4, pp.575-578.

Michalko, M. (2006) Thinkertoys (2nd ed.),Ten Speed Press, New York, NY.

Moore, E.C. (1985) American Pragmatism: Peirce, James, and Dewey, Greenwood Press, Westport, CT.

Morris, M.H., Schindehutte, M., Kuratko, D. and Spivack, A. (2012) 'Framing the entrepreneurial experience', Entrepreneurship Theory and Practice, Vol. 36, No. 1, pp.11-40.

Morris, M.H., Webb, J. W., Fu, J. \& Singhal, S. (2013) 'A competency-based perspective on entrepreneurship education: conceptual and empirical insights', Journal of Small Business Management, Vol. 51, No. 3, pp.352-369.

Muñoz C.C.A., Mosey, S. and Binks, M. (2011) 'Developing opportunity-identification capabilities in the classroom: visual evidence for changing mental frames', Academy of Management Learning \& Education, Vol. 10, No. 2, pp.277-295.

Nabi, G., Liñán, F., Krueger, N.F., Fayolle, A. and Walmsley, A. (2017) 'The impact of entrepreneurship education in higher education: a systematic review and research agenda', Academy of Management 
Learning \& Education, Vol. 16, No. 2, pp.277-299.

Neergaard, H., Tanggaard, L., Krueger, N. and Robinson, S. (2012) 'Pedagogical interventions in entrepreneurship from behaviourism to existential learning', Paper presented at Institute for Small Business and Entrepreneurship. Dublin, Ireland.

O'Connor, T. (2000) Persons and Causes: The Metaphysics of Free Will, Oxford University Press, New York, NY.

Omazić, M. A. and Vlahov, R. D. (2011) 'Educating entrepreneurs-short overview of the most innovative classes, courses and programs', in Dabić, M. and Pietrzykowski, M. (Eds.): Fostering Education in Entrepreneurship, pp.187-196, Bogucki Wydawnictwo Naukowe, Poznań, PL.

Omrane, A. (2015) 'Entrepreneurs' social capital and access to external resources: the effects of social skills', International Journal of Entrepreneurship and Small Business, Vol.24, No. 3, p.357-382.

Osterwalder, A. and Pigneur, Y. (2010) Business Model Generation, Wiley, Hoboken, NJ.

Peirce, C. S. (1965) Pragmatism and Pragmaticism, Vol. 5, Belknap Press of Harvard University Press, Cambridge, MA.

Pellegrini, M. M. and Ciappei, C. (2015) 'Ethical judgment and radical business changes: the role of entrepreneurial perspicacity', Journal of Business Ethics, Vol. 128, No. 4, pp.769-788.

Pittaway, L. A., Gazzard, J., Shore, A. and Williamson, T. (2015) 'Student clubs: experiences in entrepreneurial learning', Entrepreneurship \& Regional Development, Vol. 27, No. 3-4, pp.127-153.

Rae, D. (2005) 'Entrepreneurial learning: a narrative-based conceptual model', Journal of Small Business and Enterprise Development, Vol. 12, No. 3, pp.323-335.

Rideout, A. C. and Gray, D. O. (2013) 'Does entrepreneurship education really work? A review and methodological critique of the empirical literature on the effects of university-based entrepreneurship education', Journal of Small Business Management, Vol. 51, No. 3, pp.329-351.

Roberts, J. (1989) 'Aristotle on responsibility for action and character', Ancient Philosophy, Vol. 9, No. 1, pp.23-36.

Sánchez, J. C. (2011) 'University training for entrepreneurial competencies: its impact on intention of venture creation', International Entrepreneurship and Management Journal, Vol. 7, No. 2, pp.239254.

Schumpeter, J. (1934) The Theory of Economic Development, Harvard University Press, Cambridge, MA.

Sennett, R. (2008) The Craftsman, Yale University Press, New Haven, CT.

Shapero, A. \& Sokol, L. (1982) 'Social dimensions of entrepreneurship', in Kent, C.,Sexton, D. and Vesper, K. (Eds.): The Encyclopedia of Entrepreneurship, pp.72-90, Prentice Hall, Englewood Cliffs, NJ.

Shinato, T., Kamei, K., \& Dana, L. P. (2013). Entrepreneurship education in Japanese universities-how do we train for risk taking in a culture of risk adverseness?. International Journal of Entrepreneurship and Small Business, 20(2), 184-204.

Small, M.W. (2004) 'Wisdom and now managerial wisdom: do they have a place in management development programs?', Journal of Management Development, Vol. 23, No. 8, pp.751-764.

Smith, W. K. K., Besharov, M. L., Wessels, A. K. and Chertok, M. (2012) 'A paradoxical leadership model for social entrepreneurs: challenges, leadership skills, and pedagogical tools for managing social and commercial demands', Academy of Management Learning \& Education, Vol. 11, No. 3, pp.463-478. 
Spencer, J. and Spencer, S.M. (1993) Competence at Work, Wiley, New York, NY.

Squires, G. (2001) 'Management as a professional discipline', Journal of Management Studies, 38, No. 4, pp.473-487.

Squires, G. (2003) 'Praxis: a dissenting note', Journal of Curriculum Studies, Vol. 35, No. 1, pp.1-7.

Tan, S. S. and Ng, F. C. (2006) 'A problem-based learning approach to entrepreneurship education', Education+Training, Vol. 48, No. 6, pp.416-428.

Thursby, M. C., Fuller, A. W. and Thursby, J. (2009) 'An integrated approach to educating professionals for careers in innovation', Academy of Management Learning \& Education, Vol. 8, No. 3, pp.389405.

Tounés, A., Lassas-Clerc, N. And Fayolle, A. (2014) ' Perceived entrepreneurial competences tested by business plan pedagogies', International Journal of Entrepreneurship and Small Business, Vol. 21, No. 4, pp.541-557.

Vaida, I. C. (2009) 'A new Kantian solution to the third antinomy of pure reason and to the free will problem', The Southern Journal of Philosophy, Vol. 47, No. 4, pp.403-431.

Vesper, K. H. and McMullan, W. E. (1988) 'Entrepreneurship: today courses, tomorrow degrees?', Entrepreneurship Theory and Practice, Vol. 13, No. 1, pp.7-13.

Vesper, K. H., McMullan, W. E. and Ray, D. M. (1989) 'Entrepreneurship education: more than just an adjustment to management education', International Small Business Journal, Vol. 8, No. 1, pp.6165 .

Volanen, M.V. (2012) Theoria, Praxis, Poiesis: Individualization as the Constitution of Sociality, Jyväskylä University Press, Jyväskylä, FI.

Vorley, T. and Williams N. (2016) 'Not just dialling it in', Education+Training, Vol. 58, No. 1, pp.45-60.

Waddock, S. and Lozano, J. M. (2013) 'Developing more holistic management education: lessons learned from two programs', Academy of Management Learning \& Education, Vol. 12, No. 2, pp.265-284.

Watts, C. A. and Wray, K. (2012) 'Using toolkits to achieve STEM enterprise learning outcomes', Education+Training, Vol. 54, No. 4, pp.259-277.

Winkler, C. (2014) 'Toward a dynamic understanding of entrepreneurship education research across the campus-social cognition and action research', Entrepreneurship Research Journal, Vol. 4, No. 1, pp.69-93.

Wood, A. W. (2003) 'Kant and the problem of human nature', in Jacobs, B. and Kain, P. (Eds.): Essays on Kant's Anthropology, pp.38-59, Cambridge University Press, Cambridge, UK.

Zhao, H. and Seibert, S. E. (2006) 'The big five personality dimensions and entrepreneurial status: a meta-analytical review', Journal of Applied Psychology, Vol. 91, No. 2, pp.259-271.

Zhang, Y., Duysters, G. and Cloodt, M. (2014) 'The role of entrepreneurship education as a predictor of university students' entrepreneurial intention', International Entrepreneurship and Management Journal, Vol. 10, No. 3, pp.623-641. 
Table 1 Summary of philosophical concepts about acting

\begin{tabular}{|c|c|c|}
\hline & $\begin{array}{l}\text { GENERATE SENSE, } \\
\text { PREFERENCES, AND ACTIONS }\end{array}$ & $\begin{array}{l}\text { ORDER SENSE, PREFERENCES, } \\
\text { AND ACTIONS }\end{array}$ \\
\hline Kant & $\begin{array}{l}\text { Autos is the desiring side of the self, } \\
\text { expressing the fundamental function of } \\
\text { the orientation. } \\
\text { Such function orients the existential } \\
\text { "journey" from a certain (known) } \\
\text { condition as experience from the past } \\
\text { and the present to a condition of } \\
\text { uncertainty as the unpredictable } \\
\text { circumstances of the future. }\end{array}$ & $\begin{array}{l}\text { Nomos is the regulating side of the self, } \\
\text { expressing the fundamental function of } \\
\text { the ordering. } \\
\text { Such function regulates/orders the } \\
\text { existential "journey" from a certain } \\
\text { (known) condition as experience from the } \\
\text { past and the present to a condition of } \\
\text { uncertainty as the unpredictable } \\
\text { circumstances of the future. }\end{array}$ \\
\hline \multirow[t]{2}{*}{ Aristotle } & $\begin{array}{l}\text { Praxis is the profile of acting that } \\
\text { reflexes its results upon the self itself, } \\
\text { generating internal and personal sense } \\
\text { for the action. } \\
\text { This is the highest profile of acting } \\
\text { with the most dense of meanings, but } \\
\text { distant from the "actual action". }\end{array}$ & $\begin{array}{l}\text { (Pragma)/Pö̈esis is a combined profile of } \\
\text { acting that transfers the effect of acting } \\
\text { from the agent to the external } \\
\text { environment (pragma) and then provokes } \\
\text { an actual change of status in such external } \\
\text { environment (poïesis). } \\
\text { This combined profile of acting is less } \\
\text { dense of meanings, but nearer to the } \\
\text { "actual action" (action-full). }\end{array}$ \\
\hline & $\begin{array}{l}\text { INTERNALLY-ORIENTED AND } \\
\text { MEANING-FULL }\end{array}$ & $\begin{array}{l}\text { EXTERNALLY-ORIENTED AND } \\
\text { ACTION-FULL }\end{array}$ \\
\hline
\end{tabular}


Table 2 Mapping innovative pedagogies for entrepreneurship education

\begin{tabular}{|c|c|}
\hline \multicolumn{2}{|c|}{ Soft Core (Art) of Entrepreneurship Education Pedagogies } \\
\hline Common to the Soft core & Specific Educational Areas \\
\hline $\begin{array}{l}\text { - Student liaison and networking with entrepreneurs } \\
\text { and enterprises (Chang et al., 2014; Kuehn, 2008), } \\
\text { on e-platform (Watts and Wray, 2012) } \\
\text { - Students run a fundraising event or activity (Chang } \\
\text { et al., 2014) } \\
\text { - Reflective logs (Chang et al., 2014) } \\
\text { - Self-reflections on results and reflective learning } \\
\text { (Gondim and Mutti, 2011; Kirkwood et al., 2014) } \\
\text { - Unstructured search approach to creativity (Gudry } \\
\text { et al. 2014) } \\
\text { - Student-led research projects and inputs (Florin et } \\
\text { al., 2007; Kirkwood et al., 2014) }\end{array}$ & $\begin{array}{l}\text { Personal Attitudes: Openness, consciousness, need for achievement and autonomy, } \\
\text { tolerance for ambiguity, resilience, tenacity, perseverance, innovative propensity, vision. } \\
\text { - Appoint champions and mentors to present experiences (Burrows and Wragge, 2013) } \\
\text { - Affect and experiential learning (Gondim and Mutti, 2011) } \\
\text { - Promotion and reward of creative and original thinking in assignments and } \\
\text { - } \text { Rtracurricular activities (Florin et al., 2007) } \\
\text { - Seal entrepreneurial case studies (Boyd and Vozikis, 1994; Eriksson, 2003) } \\
\text { - Actorytelling of epic entrepreneurial life experiences (Eriksson, 2003; Rae, 2005) } \\
\text { - Field trips, visits to entrepreneurial enterprises (Hood and Young, 1993; Hytti and } \\
\text { - O'Gorman, 2004; Omazić and Vlahov, 2011) }\end{array}$ \\
\hline $\begin{array}{l}\text { - Collaboration with start-up incubators and } \\
\text { entrepreneurship centres (Florin et al., 2007; } \\
\text { Gilbert, 2012). } \\
\text { - Trading activities, e.g., external exchanges (Jones } \\
\text { and Jones, 2011). } \\
\text { - Repertory grids for entrepreneurial network } \\
\text { analysis (Klapper, 2014) } \\
\text { - Student networking clubs and websites (Brink and } \\
\text { Madsen, 2015; Burrows and Wragge, 2013; } \\
\text { Omazić and Vlahov, 2011; Pittaway et al., 2015; } \\
\text { Watts and Wray, 2012) }\end{array}$ & $\begin{array}{l}\text { Meta-competencies: Creativity, leadership, ethical sensitivity, opportunity recognition } \\
\text { and evaluation ability, risk-bearing ability, social and interpersonal skills. } \\
\text { - Creativity and divergent thinking exercises (Burrows and Wragge, 2013; Muñoz et al., } \\
\text { 2011; Smith et al., 2012); SEEC training (securing, expanding, exposing, challenging), } \\
\text { e.g., creativity diaries, deliberate system search approach (DeTienne and Chandler, } \\
\text { 2004); SCAMPER training (substitute, combine, adapt, magnify/modify, put to other } \\
\text { uses, eliminate, reverse/rearrange) (Michalko, 2006); Mind-mapping (Buzan and Buzan } \\
\text { 1996); Idea grid evaluation method (Gudry et al., 2014) } \\
\text { - Create creative tools for future undergrad students (Burrows and Wragg, 2013) } \\
\text { - Presentations to panel of external judges (Chang et al., 2014; Florin et al., 2007) } \\
\text { - Positive feedback on students' entrepreneurial achievements (Florin et al. 2007). } \\
\text { - Imaginary case studies (Abaho et al., 2015) } \\
\text { - Unstructured planning (creation, evaluation, selection from set of alternatives) } \\
\text { - Setting entrepreneurial agendas to act (Collins et al., 2006). } \\
\text { - Business and multimedia simulation (Garalis and Strazdienè, 2007; Honig, 2004; Hytti } \\
\text { and O'Gorman, 2004; Vorley and Williams, 2016; Watts and Wray, 2012) }\end{array}$ \\
\hline
\end{tabular}


Table 2 (continued)

\section{Hard Core (Science) of Entrepreneurship Education Pedagogies}

\begin{tabular}{|l|l}
\hline Common to the Hard Core & Specific Educational Areas
\end{tabular}

- Flexible and lean learning environment (Brink and Madsen, 2015; Harms, 2015)

- Implement specific project/business during program (Brink and Madsen, 2015; Galloway et al., 2005; Hytti and O'Gorman, 2004)

- Entrepreneurial events organisation/participation, e.g., innovative start-up projects fair (Burrows and Wragg, 2013)

- Networking training support (De Faoite et al., 2004)

- Use rules of thumbs for explaining entrepreneurial theories and knowledge (Gielnik et al., 2015)

- Work-based learning (innovation centre, incubators or start-ups) (Gilbert, 2012; Hytti and O'Gorman, 2004; Thursby et al., 2009)

Strategizing: Leveraging resources, business planning/modelling, network building, strategic thinking, risk management and mitigation, market orientation.

- Implement CANVAS Business Model (Osterwalder and Pigneur, 2010)

- Co-learning with nascent entrepreneurs (Collins et al., 2006)

- Business initiative design (Brink and Madsen, 2015; Chang et al., 2014; Dominguinhos and Carvalho, 2009; De Faoite et al., 2004; Muñoz et al., 2011; Tan and Ng, 2006; Tounés et al., 2014)

Organizing: Financial, accounting, and legal knowledge/skills, production and prototyping knowledge, marketing skills, human resource management, guerrilla skills, networking skills.

- Focus on learning in actual organisations (Brink and Madsen, 2015)

- Finance support/consultation (De Faoite et al., 2004)

- Training about basic support, e.g., financial funds and logistics facilities for start-up (Dominguinhos and Carvalho, 2009)

- Internships (Dobratz et al., 2015; Hytti and O’Gorman, 2004; Omazić and Vlahov, 2011)

\section{Pedagogies Common Across Educational Areas}

- Project development with real-life entrepreneurs and financiers (Chang and Rieple, 2013; Chang et al., 2014; Collins et al., 2006; Dominguinhos and Carvalho, 2009; Gilbert, 2012; Hytti and O'Gorman, 2004; Smith et al., 2012)

- Real project based learning (Muñoz et al., 2011; Tan and Ng, 2006)

- Action and action regulatory training, e.g., goal intentions, action planning, self-efficacy, action knowledge (Gielnik et al., 2015) 
Figure 1 A philosophical construction for acting

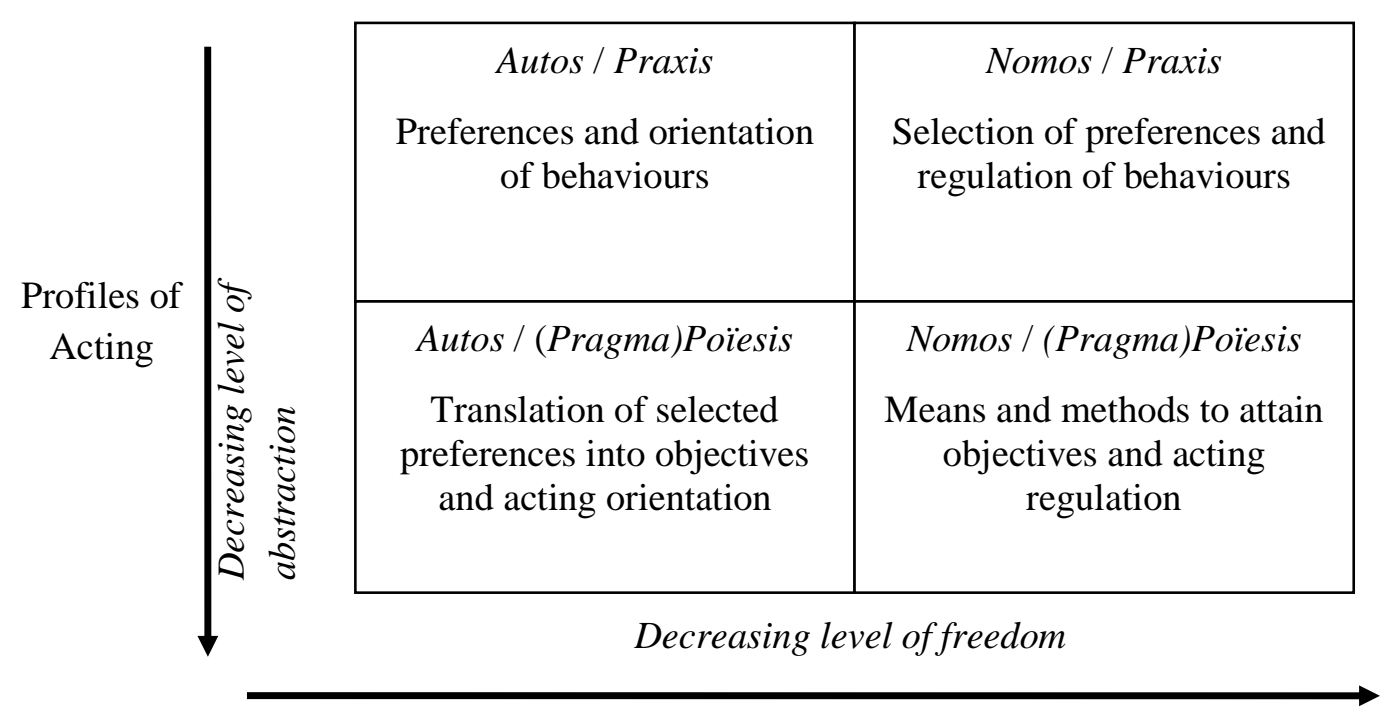

Dimensions of the Agent 
Figure 2 Entrepreneurial potential model ${ }^{\mathrm{a}}$

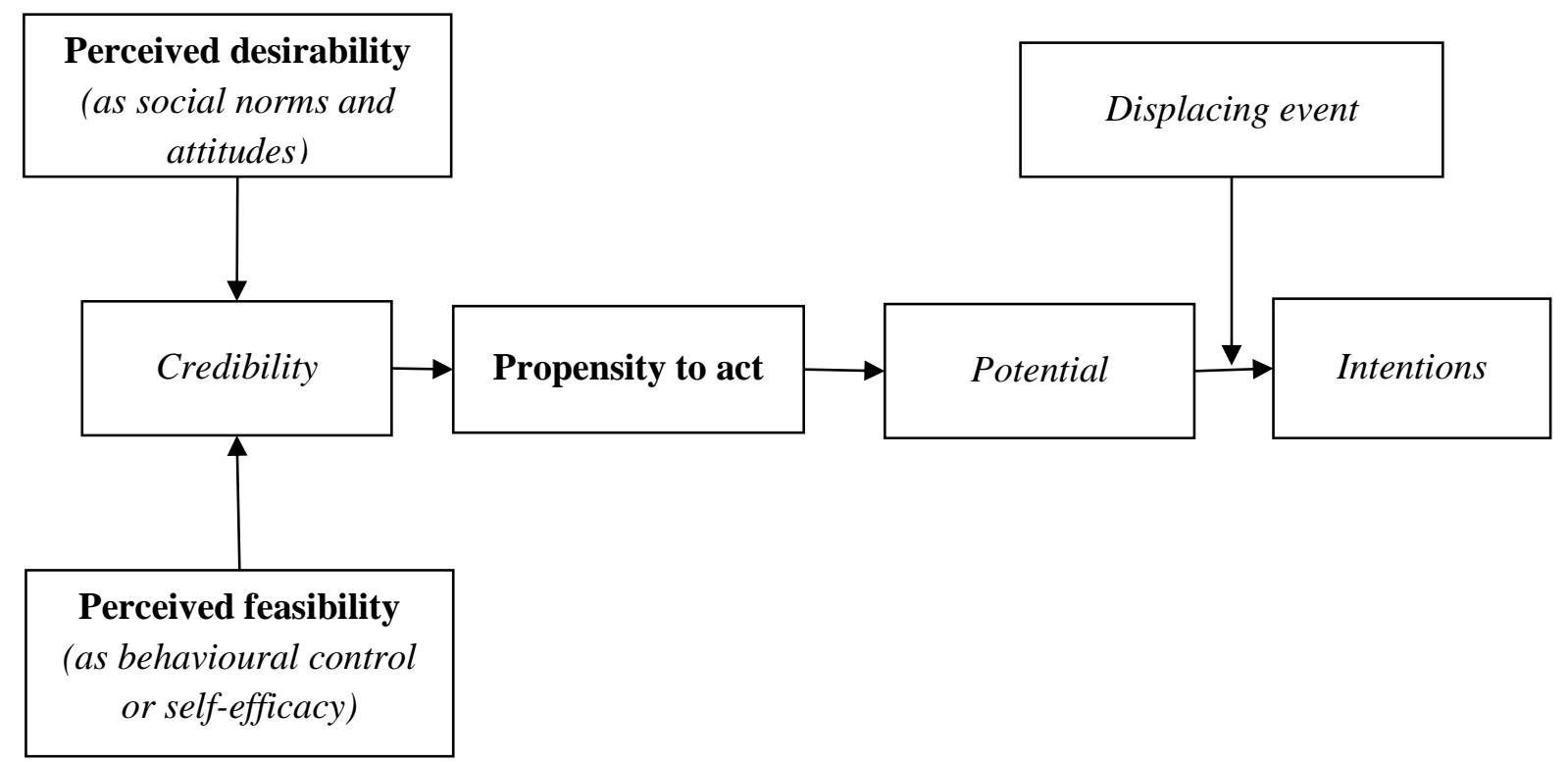

${ }^{a}$ Adapted from Krueger and Brazeal (1994, pp.95). Bold font indicates concepts in our model. 
Figure 3 A comprehensive model of entrepreneurship education

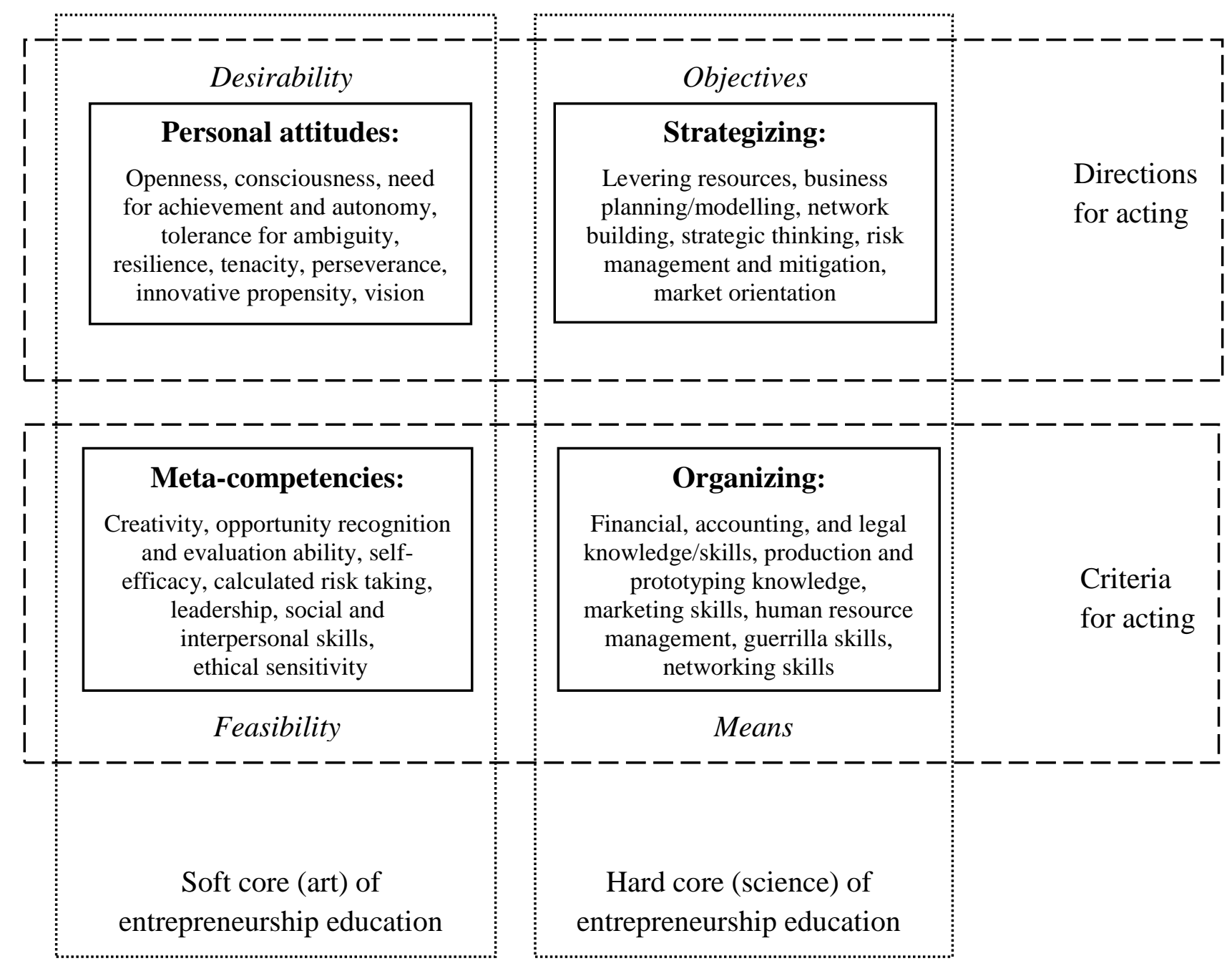

